University of Michigan Law School

University of Michigan Law School Scholarship Repository

1908

\title{
Grantor's Remedy on Breach of Condition Subsequent
}

\author{
James H. Brewster \\ University of Michigan Law School
}

Available at: https://repository.law.umich.edu/articles/1194

Follow this and additional works at: https://repository.law.umich.edu/articles

Part of the Property Law and Real Estate Commons

\section{Recommended Citation}

Brewster, James H. "Grantor's Remedy on Breach of Condition Subsequent." Mich. L. Rev. 6 (1908): 409-10.

This Response or Comment is brought to you for free and open access by the Faculty Scholarship at University of Michigan Law School Scholarship Repository. It has been accepted for inclusion in Articles by an authorized administrator of University of Michigan Law School Scholarship Repository. For more information, please contact mlaw.repository@umich.edu. 
Grantor's Remedy on Breach of Condition Subsequent.-In Mash v. Bloom (Igo7), - Wis. -, II4 N. W. Rep. 457, the court holds (SIEBECKER and TrmLis, JJ., dissenting) that one, having conveyed real property subject to a condition subsequent, has no right of action to recover possession on breach of the condition until he has taken "advantage of condition broken and so notified the defendant, either by demand of possession or some other act equivalent to a re-entry for condition broken."

The plaintiff had made a deed of conveyance of the premises in question in consideration of $\$ \mathrm{r} .00$, natural love and affection, and upon the "special considerations and conditions" that defendant and his wife should care for the plaintiff and administer to her natural wants "as good, loving, affectionate and kind children would do for a parent." The plaintiff had previously sought by a suit in equity to enforce her rights under the deed, and had asked to have it cancelled as a cloud on her title, but the court had held that she had a complete and adequate remedy at law and might enforce her rights 
in, ejectment without resorting to equity: Mash v. Bloom, Iso N. W. Rep. 203, 268. The parties had appeared before the court on the same matter several times (see $105 \mathrm{~N}$. W. Rep. 83I ; II4 N. W. Rep. 99), so that the defendant had had notice of the nature of the plaintiff's demands. A statute of the state provides (St. Wis. $1898, \$ 3079$ ) that it shall not be necessary for a plaintiff in ejectment "to prove an actual entry under title nor the actual receipt of any profits of the premises demanded, but it shall be sufficient for him to show a right to the possession of such premises at the time of the commencement of the action as heir, devisee, purchaser or otherwise." Therefore, the circumstances of the case seem to have been such as to warrant the court in disregarding the ancient rule which required a re-entry by the grantor, upon breach of a condition before bringing an action to recover possession.

It was certainly true once that no estate of freehold could be made to cease, without entry, upon the breach of a condition: an estate of freehold could not begin nor end without ceremony (Co. Litt. 214 b.); and recent decisions, other than those cited by the majority of the court in the principal case, may be found sustaining the proposition that there must be a re-entry by the plaintiff, or at least a demand of possession and refusal by the defendant if peaceable re-entry cannot be made. (See, for example, Randall v. Wentworth (1905), 100 Me. 177, 60 Atl. 871; Moss v. Chappell, 126 Ga. 196, 54 S. E. 968; Preston v. Bosworth, 153 Ind. 458, 55 N. E. 224, 74 Am. St. Rep. 313.)

On the other hand, either because of statutes not unlike that of Wisconsin, or because of the implied or express confession of lease, entry and ouster in the action of ejectment, it is held in other recent decisions that an actual entry for condition broken is no longer necessary, but that ejectment will lie, without demand of possession or notice. Under the Washington statute, for - instance (Ball. Co. $\$ 5500$ ), providing that one having a valid interest in real property and a right to possession may maintain ejectment, it is held that neither entry nor demand of possession prior to the commencement of an action to recover property for breach of condition is essential. Lezviston Water \& Power Co. v. Brown, 42 Wash. 555, 85 Pac. Rep. 47. And it was expressly held in Trustees of Union College v. City of Nezo York (1903), I73 N. Y. 38,65 N. E. 853,93 Am. St. Rep. 569, that proof of demand of possession before commencing the action of ejectment on breach of condition was unnecessary, and in Gray v. C. M. \& St. P. Ry. Co., I89 Ill. 400, the plaintiff was apparently permitted to sue at once upon breach of the condition. The prevailing doctrine seems to be that the "commencement of the action stands in liew of entry and demand of possession." Cowell v. Springs Co., 100 U. S. 55 ; Sioux City and St. P. R. Co. v. Singer, 49 Minn. 30r, $5 \mathrm{I} \mathrm{N.} \mathrm{W.}$ 905, I5 L. R. A. 75I, 32 Am. St. Rep. 554; Ritchie v. Kan. N. \& D. R. Co., 55 Kan. 36; Austin v. Cambridgeport Parish, 21 Pick. 215; Brown v. Bennett, 75 Pa. St. 420. 